\title{
80 celling black bodies: black women in the global prison industrial complex
}

\author{
Julia Sudbury
}

\section{abstract}

The past two decades have witnessed an explosion in the population of women prisoners in Europe, North America and Australasia, accompanied by a boom in prison construction. This article argues that this new pattern of women's incarceration has been forged by three overlapping phenomena. The first is the fundamental shift in the role of the state that has occurred as a result of the neo-liberal globalization. The second and related phenomenon is the emergence and subsequent global expansion of what has been labeled a 'prison industrial complex' made up of a intricate web of relations between state penal institutions, politicians and profit-driven prison corporations. The third is the emergence of a US-led global war on drugs which is symbiotically related and mutually constituted by the transnational trade in criminalized drugs. These new regimes of accumulation and discipline, I argue, build on older systems of racist and patriarchal exploitation to ensure the superexploitation of black women within the global prison industrial complex. The article calls for a new anti-racist feminist analysis that explores how the complex matrix of race, class, gender and nationality meshes with contemporary globalized geo-political and economic realities. The prison industrial complex plays a critical role in sustaining the viability of the new global economy and black women are increasingly becoming the raw material that fuels its expansion and profitability. The article seeks to reveal the profitable synergies between drug enforcement, the prison industry, international financial institutions, media and politicians that are sending women to prison in ever increasing numbers.

\section{keywords}

war on drugs; globalization; prison industrial complex. 


\section{introduction}

My mother got twelve years. She's in Foston Hall. They can give people those long sentences just for knowing drugs are in the house. He sentenced her to 12 years for knowing. She wasn't even involved and he knew that. But he said she knew it was in the country and if it had got through, she would have benefited from it, from any money. He said one only has to read the papers every day to know the trouble it causes once it gets in the pubs and clubs, what it does to people. There was a recorder in the cage and she was saying: 'Why did you do it?' They convicted her on that

(Janet, HMP Holloway).

1 Between 1999 and 2001 I interviewed 50 women in prisons in England, Canada and the US. All names of women prisoners are psyeudonyms.
Janet $^{1}$ is an African Caribbean woman in her mid-twenties serving a seven year sentence for importation of Class A drugs. She was six months pregnant when she was arrested at Heathrow airport and brought to HMP Holloway, England's oldest and most notorious women's prison. After having her son, she was transferred to the Mother and Baby Unit where I interviewed her. In this 'compassionate' penal environment, designed to punish the mother but not her innocent child, Janet and son are confined to a $6^{\prime}$ by $8^{\prime}$ cell with a bed, toilet and closet from 8 PM to 8 AM. During the day, they have intermittent access to a creche, playroom and roof garden where the baby can breathe fresh air under wire mesh designed to prevent escape attempts. When her son reaches nine months, Janet will be transferred to another unit where she can keep him for a further nine months, at that stage, they will be separated while she serves the remainder of her sentence. While Janet was sentenced to a 'lenient' seven years because of her guilty plea, her mother, who was not involved in the drug trade, was sentenced to 12 years because of her failure to report her daughter to the police.

Janet, her mother and her son represent three generations caught up in an ever expanding network of penal repression and profit that increasingly defies national borders. The past two decades have witnessed dramatic increases in women's incarceration accompanied by expansive prison building programs in Britain as well as the rest of western Europe, North America and Australasia. At the same time, there has been a shift in the nature of confinement as the private prison industry has been embraced by New Labour and Conservatives alike, and the deprivation of liberty has become an extremely profitable enterprise. This article will argue that the explosion in women's incarceration is the hidden face of neo-liberal or 'corporate' globalization and can not be understood without reference to three overlapping phenomena. The first is the fundamental restructuring of national economies and social welfare provision that has occurred as a result of the globalization of capital. The second and related phenomenon is the emergence and subsequent global expansion of what has been labelled a 'prison industrial complex' made up of a intricate web of relations between state penal institutions, politicians and profit-driven prison corporations. The third is the emergence of a 
US-led global war on drugs which is symbiotically related and mutually constituted by the transnational trade in criminalized drugs. ${ }^{2}$ These new regimes of accumulation and discipline, I will argue, build on older systems of racist and patriarchal exploitation to ensure the super-exploitation of black women and women of colour $^{3}$ within the global prison industrial complex.

\section{the global boom in women's imprisonment}

Since the early 1990s, increases in the prison population in England and Wales have sparked a boom in prison construction, leading commentators to comment on 'the largest prison building program since the middle of the 19th century' (Morgan, 1999: 110). While women make up a small proportion of those incarcerated, their rates of imprisonment have multiplied faster than men's, causing feminist activists to call for drastic measures to counter 'the crisis in women's prisons'. ${ }^{4}$ Between 1985 and 1998, for example, the number of women in prison more than doubled, from 1,532 to 3,260 (Prison Reform Trust, 2000). The prison service has responded by contracting with private corporations to built and operate new prisons, and by re-rolling men's prisons for women. Recent government initiatives designed to slow the increase in the use of incarceration, such as Home Detention Curfews, have had little impact on the number of women sentenced to prison which continued to grow during the year to April 2001 by $9 \%$, compared to $2 \%$ for men.

The British pattern is mirrored elsewhere. In the US, where the prison and jail population reached two million in the year 2000, women's incarceration is also spiraling upwards at a greater pace than that of men. While the number of men in US prisons and jails doubled between 1985 and 1995, women's imprisonment during the same period tripled (Department of Justice, 1998). In 1970, there were 5,600 women in federal and state prisons, by 1996, there were 75,000 (Currie, 1998). In Australia, a surging women's prison population, accompanied by pressure from activist organizations, forced the Parliament of New South Wales to commission a Select Committee on the Increase in Prisoner Population (Bacon and Pillemer, 2000). The Select Committee was instructed to investigate a $20 \%$ increase in men's and $40 \%$ increase in women's incarceration (Parliament of New South Wales, 2001). In Canada, the increase in federally sentenced women prisoners, accompanied by pressure from penal reform organizations, has led to the construction of five new federal prisons for women (Hannah-Moffatt and Shaw, 2000). In Ontario, spiraling numbers of prisoners have fueled the construction of three 1600-bed superjails where a growing women's population will be warehoused within US-style, austere coed facilities.

Aggregate rates of increase in prison populations under-represent the impact of the prison boom on black women, women of colour and indigenous women. In all the countries mentioned above, oppressed racialized groups are disproportionately represented. For example, in New South Wales, while all women's imprisonment
2 The 'threat' of drugs can be seen to be socially constructed in so far as some drugs with addictive properties and damaging social consequences including violence and theft (tobacco, alcohol) are sold to the public legally under government license, and others (heroin, cannabis, cocaine) are criminalized. In addition, substances that are illegal in one context (alcohol during Prohibition), may be enjoyed legally in another. Others may be simultaneously legal and illegal (medical marijuana in

California).

Referring to

'criminalized' rather than 'illegal' drugs reminds us that 'the criminal', like 'the crime' she commits are products of penal regimes that shift over time.

3 Writing about gender and race transnationally generates problems of naming, since racial terms have different meanings depending on location. In this article, I use 'black' as the common term for women of African, Caribbean and Asian origins in Britain only; since 'black' in the US and Canada refers only to women of African descent, I use 'women of colour' to refer to women of African, Asian, Latin American and indigenous communities transnationally. I also use the term 'women of the global south' since this is now widely used by 
activists to refer to women in what is often, and problematically called 'the Third World'.

4 'The Crisis in Women's Prisons', Press Release, Leeds Metropolitan University, April 7, 1999 http// www.Imu.ac.uk news/press/archive/ apr99/prisons.htm.

5 British officials have changed the way in which they report ethnic origin in order to downplay the number of black women and men in prison. By excluding non British passport-holders, the Home Office

Research

Development

Statistics unit has

'reduced' the proportion of African Caribbean women prisoners by $51 \%$ to $12 \%$ of prisoners, compared to $1 \%$ of the general population (Elkins et al., 2001). However this is revealed to be a sleight of hand if one considers the large number of black British residents who hold 'commonwealth' passports. increased by $40 \%$ in 5 years, aboriginal women's incarceration increased by $70 \%$ in only two years. In Canada, aboriginal people comprise $3 \%$ of the general population and $12 \%$ of federal prisoners, a figure that increases to over $60 \%$ in provinces like Saskatchewan and Alberta (Canadian Criminal Justice Association 2000). African Canadians are also disproportionately policed, prosecuted and incarcerated (Commission on Systemic Racism in the Ontario Criminal Justice System 1994). In the US, Latinas and African American women make up $60 \%$ of the prison population. And despite their small numbers in the population, Native Americans are ten times more likely than whites to be imprisoned (Rojas, 1998). Finally, $12 \%$ of women prisoners in England and Wales are African Caribbean British passport holders ${ }^{5}$ compared to $1 \%$ of the general population (Elkins et al., 2001 ). In addition, British prisons hold numerous women from West Africa, the Caribbean and Latin America, either as immigration detainees, or serving sentences for drug importation. The crisis of women's prisons can therefore be read as a crisis for black women and women of colour worldwide.

\section{the emergence of the prison industrial complex}

Activist-intellectuals in the US have traced the emergence of what has been labelled the 'prison industrial complex' to the economic transformations of the 1970 s (Davis, 1998, Goldberg and Evans 1998). As advances in technology enabled corporations to transport information and capital between distant geographic locations in fractions of a second, new forms of globalized capital began to appear. US-based corporations downsized their unionized Western workforces and relocated manufacturing operations to locations in the global south where labour was cheap and labour and environmental protections minimal. Multinational trade agreements such as NAFTA and GATT and the establishment of Free Trade Zones hastened the process, opening the doors to the unhindered super-exploitation of predominantly young women of colour from Tijuana to Manila. The impact of massive downsizing in the US on urban African American and Latino communities was catastrophic. Redlining and racist violence had kept African Americans and Latinos out of the 1950 s suburbanization drive that had allowed many working class white families to move out of the inner cities, restricting the former to urban ghettos where they were warehoused with few opportunities for mobility (Oliver and Shapiro, 1995). As job cuts hit these communities, they were devastated by pandemic rates of unemployment, a declining tax base and resultant cuts in social, welfare, educational and medical provision. The result: spiraling rates of poverty, drug addiction, violence and social dislocation. These conditions were not met passively. The Black Liberation Army, Black Panthers, Young Lords, Chicano Power and American Indian movement were the organized voice of the resistance that sprung from these oppressive conditions. However these movements encountered brutal repression and criminalization. The FBI's Counter Intelligence 
Program (COINTELPRO) identified the Black Panthers as THE number one threat to the security of the US and targeted activists such as Assata Shakur, Pam Africa and Angela Y. Davis for 'neutralization' via trumped up charges, massively publicized manhunts and incarceration in maximum security institutions (Churchill, 1990). The scene had therefore been set for the mass criminalization of African Americans, American Indians and Latinos. In the white imagination, black protest was synonymous with lawlessness and violence. While overt Jim Crow racism had waning public acceptance in this post-Civil Rights era of Martin Luther Kingesque integrationist policies, criminalization provided a new camouflaged racist language in which code words such as 'criminal', 'drug dealer' and 'welfare queen' could be used to refer obliquely to the racialized 'enemy within' (Davis, 1998: 66). Criminalization therefore became the weapon of choice in dealing with the social problems caused by the globalization of capital and the protest it engendered.

Joel Dyer argues that three components make up the 'perpetual prisoner machine' that transforms criminalized populations in the US into fodder for the prison system and has caused the prison population in the US to increase tenfold in twenty years (Dyer, 2000). The first is the consolidation of large media corporations that rely on violent and crime-oriented content to grab ratings and that have created a dramatic rise in the fear of crime in the US population at large. The second is the increasing use of polling and market research by politicians to align their platforms with 'popular' views about policy areas, leading to 'tough on crime' rhetoric on both sides of the electoral spectrum. This rhetoric is translated into policies such as mandatory minimums, truth-in-sentencing and three strikes that cause more people to serve prison sentences, for longer terms and leads to spiraling prison populations. The third is the intervention of private prison corporations such as Wackenhut Corporation and Corrections Corporation of America which provide a way for governments to expand their prison estate without having to spend the initial capital cost of prison construction. The mutually profitable relationship between private corporations and public criminal justice systems enables politicians to mask the enormous cost of their tough-on-crime policies by sidestepping the usual process of asking the electorate to vote for 'prison bonds' to raise funds to build publicly operated prisons. Instead, they can simply reallocate revenue funds from welfare, health or education into contracts with privately run for-profit prisons. Since the 1980 s, the private sector has allowed prison building to continue, even where public coffers have been exhausted by the prison construction boom. It has been rewarded with cheap land, tax breaks and discounts in sewage and utilities charges, making prison companies a major beneficiary of corporate welfare. These three components constitute the 'political and economic chain reaction' that we have come to know as the prison industrial complex: a symbiotic and profitable relationship between politicians, corporations, the media and state correctional institutions that 
generates the racialized use of incarceration as a response to social problems rooted in the globalization of capital.

\section{the PIC goes global}

Although the prison industrial complex emerged in the US, the past 15 years have witnessed its transformation into a global phenomenon. Multinational prison corporations have fueled this expansion through an aggressive strategy of pursuing foreign markets through sophisticated marketing techniques. Targeting British politicians has proven particularly fruitful. During the 1980s, Labour and Conservative politicians were invited to the US for tours of flagship private prisons where the new steel and glass buildings and latest technological advances in surveillance appeared to offer a striking advance over Britain's decaying penal estate. The glossy rhetoric of the 'new corrections' where prisoners were called 'residents', prison guards 'supervisors' and cells 'rooms' was favourably compared to the brutal and dehumanizing prison culture in Britain which had long proved resistant to reform. Prior to this time, both sides of the House of Commons were opposed to prison privatization. Politicians tended to view the denial of freedom as too serious an undertaking to be entrusted to private interests and subjected to the vagaries of the profit motive. But these carefully orchestrated visits led to a sea-change. As Sir Edward Gardner, Chair of the all-party penal affairs group commented after a visit to the US in 1986: 'We thought it was stunning. These places didn't feel like prisons and didn't smell like prisons. There was nothing we could find to criticize' (Young, 1987: 3).

In 1987, a Home Affairs Select Committee visited four adult and juvenile jails run by the Corrections Corporation of America and the Radio Corporation of America. The Select Committee subsequently recommended that corporations should be invited to bid for contracts to build and manage custodial institutions, initially as an experiment. A key to the recommendation was that privatization would dramatically accelerate the prison building program, which was hindered by lack of public funds (Speller, 1996: 5). Gradually, key British politicians and administrators were won over to the possibilities for cost cutting, modernization and prison expansion offered by the corporate agenda. Privatization was presented as a panacea to the problems facing the prison service: overcrowding, old buildings, high annual costs, resistance to reform and a rigid prison guard culture reinforced by the powerful Prison Officers Association. Between 1991 and 1994 the mutually profitable relationship between conservative politicians and the prison industry culminated in a series of Acts which allowed for corporations to design, construct, manage and finance new prisons and to bid to operate existing prisons FN [5]. By 1997, when New Labour came to power, Britain had become a profitable location for multinational prison corporations, producing revenues of over $£ 95$ million for the five leading private incarcerators, Premier Prison Services (a joint 
venture of Wackenhut and Sodexho), Wackenhut (UK) Ltd., UK Detention Services (a joint venture of Corrections Corporation of America and Sodexho), Securicor and Group 4 (Prison Privatisation Report International, 1998a; Sudbury 2000). Although Labour had condemned the Conservative privatization program, pre-election promises to return prisons to the public sector were short lived (Prison Privatisation Report International, 1996). Within a year of election, Home Secretary Jack Straw announced that privately run prisons would only return to the public sector if the latter could outbid their private competitors, and that new prisons would be built under the Private Finance Initiative (Prison Privatisation Report International, 1998b).

While Wackenhut Corporation, Corrections Corporation of America and others have reaped enormous profits in the US since the 1980s, their profits have recently been compromised. A radical popular prison movement, and a series of high profile legal cases have pushed the US prison industry into a period of crisis as shares go into freefall. ${ }^{6}$ Critical Resistance, the Prison Moratorium Project and the Black Radical Congress' 'Education not Incarceration' campaign have mobilized popular support and media coverage in questioning the logic of ever increasing incarceration. At the same time, private prisons corporations have proven vulnerable to the 'Jena' effect, whereby a case of malpractice turns the tide of popular and political sentiment and corporations are left with legal costs and empty facilities due to cancelled contracts. ${ }^{7}$ Potentially damaging incidents of prisoner abuse, sexual assault, violence and protests are generated by the very conditions that make prisons profitable: low paid non-unionized staff, low staffing ratios and sparse provision of activities for prisoners (Yeoman, 2000). Although corporations engage in a process of damage limitation, whereby they seek to suppress public knowledge about such incidents, close scrutiny by prison activists has severely limited their ability to do so. As domestic profits come under threat, foreign operations play a key role in maintaining corporate viability. New prisons in Marchington, Olney and Peterborough therefore play an important role in maintaining the viability of the multinational prison industry as it seeks new markets in South Africa and further afield (Martin, 2001). Women and men serving time in British prisons thus fuel stock market profits from London to New York, reinforcing the logic of incarceration with the logic of capitalist accumulation.

\section{the war on drugs wages war on women}

With the entering of the New Year, I want to give you the gift of vision, to see this system of Modern Day Slavery for what it is. The government gets paid $\$ 25,000$ a year by you (taxpayers) to house me (us). The more of us that they incarcerate, the more money they get from you to build more prisons. The building of more prisons create more jobs. The federal prison system is comprised of $61 \%$ drug offenders, so basically this war on drugs is
6 Between 1998 and 2000, Corrections Corporation of America (aka Prison Realty) shares fell from $\$ 40$ to $\$ 2$, Wackenhut shares fell from $\$ 30$ to $\$ 9$ (Martin, 2001).

7 In September 2000 , the State of Louisiana agreed in federal court to cease contracting with privately run juvenile facilities after an investigation found boys in Wackenhut's Jena facility had been abused with pepper spray and tear gas and denied basic needs from underwear to food (Martin, 2001). 
8 Kemba Smith's case is a composite of factors which make her both representative of and different from the majority of women incarcerated as a result of the war on drugs. As an African American woman, young mother and victim of domestic violence, she is typical enough to become a symbol of the anti-war on drugs campaign. As a middle class, articulate student, she is clearly untypical, yet her class status strengthens the message to 'middle America', that this could happen to 'your daughter'.
9 This has not been the case, instead, criminalization and targeting by law enforcement artificially inflate the price of drugs, so that manufacturing, trafficking and selling them become immensely profitable and increasingly associated with violence. This the reason why the Prison Industrial Complex is a skyrocketing enterprise (Kemba Smith, 1999).

In 2000 two African American women were among the prisoners granted clemency by outgoing President Clinton. Dorothy Gaines and Kemba Smith's cases had been highlighted by organizations including Families Against Mandatory Minimums, the Kemba Smith Justice Project and the Million Woman March as evidence of the egregious injustices occurring as a result of the 'war on drugs' and the particular impact on women. Kemba Smith's case in particular attained national attention and was widely reported in the mainstream press. ${ }^{8}$ Kemba was a student at Hampton College, a traditionally black college in Virginia. She became involved with a young man, Khalif Hall, who, unknown to her, was a key figure in a large drug operation. Kemba stayed with Hall despite abuse and threats to kill her because she was afraid for her family and herself and because she had become pregnant. Shortly before the drug ring was apprehended, Hall was shot and killed. Kemba pleaded guilty to conspiracy to distribute crack cocaine, but hoped Hall's abusive behaviour would be taken into account. Instead, she was held responsible for the full $255 \mathrm{~kg}$ involved in the offense, although she personally was not found to have handled the drugs, and was sentenced to 24.5 years in prison. Kemba, like Janet and her mother (above) have been targeted by a transnational war on drugs that emerged in the mid 1980s in the United States and has since been aggressively exported around the globe. While the shadowy figure of the drug dealer or trafficker tends to be envisioned in the popular media as male, increasingly women are the low level 'footsoldiers' within the transnational drug trade who are most vulnerable to arrest and punishment.

The current war on drugs was announced by Ronald Reagan in the early 1980s and formalized in the 1986 Anti Drug Abuse Act. The Act made a critical break with the concept of drug users as a medical population in need of treatment, and instead targeted them as a criminal population. It also utilized the erroneous assumption that users would be deterred from their habit and dealers and traffickers incapacitated by punitive and extensive use of penal sanctions. By removing those involved in the criminalized drug trade from the streets for long periods of time, it was assumed, syndicates would be severely damaged in their ability to get drugs to the streets. ' Since 'liberal' judges could not be trusted to hand down sufficient sentences to deter and incapacitate those involved in the drug trade, the Act removed discretion and imposed mandatory minimum sentences. Thus treatment programmes and community service were effectively barred in cases involving drugs, and sentences length related not to the role of the defendant in the offense, but to the weight and purity of drugs involved. In the US, African American women and Latinas are disproportionately affected by mandatory minimums. Since the only way a lesser sentence can be given is in cases where the defendant provides 'substantial assistance' in the prosecution of another person, women, who tend to be in subordinate positions within drug syndicates and thus 
have little access to information are usually unable to make such an agreement. The crack-cocaine disparity also feeds the disproportionate impact on women of colour. The mandatory minimum sentence for crack cocaine is 100 times harsher for crack than for powder cocaine. Since crack is cheaper, and has flooded poor inner city neighbourhoods, African Americans and Latinos receive disproportionate sentences when compared with white powder cocaine users and dealers (Waters, 1998).

While the war on drugs has had a dramatic impact on US communities of colour, it has reached far beyond US borders. ${ }^{10}$ From the mid-1980s, the war on drugs increasingly played a key role in US foreign policy decisions as Reagan and Bush administrations pushed a US drug agenda on the global community. Initial efforts focused on the G-7 countries as the Reagan administration used US economic clout to push for international compliance with US drug policy. In 1988 the Toronto Summit endorsed a US proposed taskforce which in turn led to the 1988 United Nations Convention Against Illicit Traffic in Narcotic Drugs and Psychotropic Substances (Friman, 1996). The Convention contained a number of controversial conditions that ran counter to the policies of other member states. By requiring states to criminalize drug cultivation, possession and purchase for personal use, maximize the use of criminal sanctions and deterrence and limit early release and parole in drug related cases, the Vienna Convention represented the transnational spread of the US punitive 'law and order' agenda (Jorg-Albrecht, 2001). By signing the Convention, member states signed onto the logic of incarceration, pledging to use criminal justice sanctions in place of medical or social solutions and turning decisively away from legalization. ${ }^{11}$ By the mid-1990s, Canada, Australia, New Zealand, Taiwan, South and Central America, the Caribbean and African countries including Nigeria and South Africa were fully fledged partners in the US driven transnational war on drugs.

The Americanization of drug policy is evident in the British approach to criminalized drug use, trafficking and retail. While the 'British System' of prescribing heroin or methadone to addicts, dating to the $1920 \mathrm{~s}$, indicates a medical approach to drug use, it exists uneasily alongside recent developments that draw on the US model of criminalization and incarceration. UN Conventions are not the only way in which US drug policy is exported abroad. Indeed, British politicians on both sides of the house have 'gratefully accepted and sometimes sought' the 'benevolence, advice, influence and leadership' of the US on drug matters (Bean, 2001: 90). US-British synergy on drug policy comes about as a result of exchanges of research findings, fact-finding missions to the US by politicians and administrators, international conferences and visits by 'specialists' to Britain. An infamous case involves Drug Enforcement Agent Robert Stutman's 1988 visit to Britain. Addressing the Assistant Chief Police Officers Conference, Stutman 'scared the hell' out the participants with his apocalyptic visions of the crack epidemic in the US and its inevitable migration to Europe as the US market mutually profitable relationship between law enforcement and the drug trade has been labeled the 'international drug complex' (Van Der Veen, 2000).

10 In Latin America, the war on drugs has been a military war. Since 1989, Colombia has seen deployment of US military personnel, financial assistance for policing, provision of attack helicopters and weaponry to assist in the fight against 'narcoterrorists'.

This fight has been closely associated with counter insurgency measures against left wing guerillas such as the FARC and ELN and has thus fuelled a bitter civil war. US counter-drug measures have also included spraying of crops with herbicides including Agent Green which indigenous groups claim has destroyed the rainforest and polluted the water table. For the impact of the war on drugs on Colombian women, see Sudbury (2001).

11 Although Dutch coffee shops selling cannabis and the British practice of prescribing to heroin addicts have gone largely unaffected by the 1988 Convention, they are in opposition to and theoretically threatened by its provisions. 
12 In Winter 2000 , the Metropolitan Police received $£ 800,000$ to carry out Operation Crackdown, targeting low level dealers of crack and class A drugs on council estates in boroughs with large black populations. The Operation led to surveillance of 700 private properties, over 80 raids and 1,000 arrests (' 1,000 arrested in London Class A drugs offensive', Press release, Metropolitan Police $01 / 03 / 2001)$. An evaluation of the Operation found it became saturated. Stutman's account was based on an unpublished report and anecdotal evidence. Nevertheless, a 1989 Home Affairs Committee Report echoed Stutman's unsubstantiated argument that there is 'no such person as a fully recovered crack addict' and that crack, by its very nature, called for a penal, rather than a medical response (Bean, 2001). Stutman's presentation had immediate and racialized effects. From the late 1980s, the press ran reports of crack infiltrating British cities. Crack became a foreign threat, an enemy brought into Britain by Yardies, with African Caribbean communities as the Trojan Horse enabling the foreign infiltration. As a result, resources were pumped into law enforcement activities such as Operation Dalehouse and the Crack Intelligence Coordinating Unit specifically to increase the surveillance and policing of black communities. Coinciding with the entrenchment of 'Fortress Europe, the crack threat was also a justification for a heightened suspicion of black British women and men entering Britain after vacations abroad, as well as Caribbean nationals entering to visit family and friends. With such targeted policing and customs attention, the numbers of African Caribbean women and men apprehended for possession, sales and importation of both class $A$ and lesser drugs increased dramatically. In some instances, retail of crack was largely inspired by police operations and protection of informants, as is the case in a northern city where a senior police officer admitted that undercover police buyers stimulated demand that disappeared once the police operation was over (Joyce, 1998: 179). While the belief that Britain was on the verge of a US-style 'crack epidemic' was found by the mid $1990 \mathrm{~s}$ to be a 'media inspired panic' (Joyce, 1998: 181), the pattern of targeted surveillance has continued unabated. As public funds are poured into the high-tech policing of black suspects, a self-fulfilling cycle is generated whereby increased arrests in the black community reinforce the public fear of African Caribbean drug dealers and traffickers, legitimate the continuation of racially discrepant policing practices and generate additional resources for the police. ${ }^{12}$ The impact on black women has been devastating. While in $1980,4.4 \%$ of women serving time in prisons in England and Wales were incarcerated on drug related offenses, by 2001 that figure had risen to 39\% (HMSO; 1982, Elkins et al., 2001). Between April 2000 and April 2001 alone, the number of women sentenced to prison as a result of the war on drugs grew by $20 \%$ (Elkins et al., 2001).

As the risk of apprehension at Heathrow, Toronto or New York increases, drug syndicates find it increasingly profitable to use black women and women of colour as low level 'mules' to carry drugs through customs. Women are seldom involved in the planning and organization of drug trafficking, nor are they party to the large profits involved (Harper and Murphy, 1999). Male dealers may believe that women will be less likely to come under suspicion of carrying drugs and more likely to receive lenient sentencing if they are apprehended. However, black women are not the recipients of such chivalrous behaviour, since they do not fall under the benevolent patriarchal protection of the white men who judge them. Nicole, a 29- 
year-old Black British woman incarcerated with her daughter at HMP Holloway explained:

The judge when he sentenced me said he's going to use me as an example. Because he knows I've been set up, but he has to give a message the world: 'Don't bring drugs'. He used me as an example because he knew I was pregnant. I was set up by a friend of mine, if you can call him that. And they knew that. But still he said that's why they're using women to bring drugs to the country because they think that the system is not going to be as hard on women as on male prisoners. He said that's not the case.

The women I interviewed became involved in the transnational drug trade through three paths: economic need; threats and coercion; and deception. Faced with poverty and often without a second income to support the family, many women make the choice to risk carrying drugs, sometimes believing it will be a one-off. Interviewees often had specific financial goals, such as an emergency medical bill, or school fees for a son or daughter. Marta, a Jamaican mother of four serving a five year sentence at HMP Winchester explained:

They do it mainly for the kids, to support the kids. You have a mother who has four or five kids, two is very sickly, every time she visit the hospital or the doctor, you have to pay to register, you have to pay for medicine, your have to pay for an X-ray. Everything costs money. So anything comes up they're going to jump at it, the easiest way to make money.

Marta is typical of women who import out of economic necessity. Knowing little about the punitive criminal justice system that awaited her in Britain, she took a calculated risk based on the limited options available for her to ensure the survival of herself and her children:

I was self employed doing a bit of selling. I was married but my husband wasn't supportive after sending the kids to school and the money kept going down. I never knew nothing much about drugs, the only form of drugs I know is ganja, we call it weed. That's the only hard drugs I've known of in my life until I come here. And I was just asked by somebody to carry some baggage for $\$ 100,000$ Jamaican dollars and I just jump at it, thought it could really help out. They said there is no risk involved, they make it look so easy, just carry the drugs and collect your money and that's it and come back. They didn't show me the possibility that I could get caught, just do it.

While Marta was not told explicitly that she was importing drugs, the fee involved made it evident to her that the package was illegal. In contrast, Maureen, a middle class North Londoner of Jamaican ancestry and mother of six was unaware of the contents of her luggage. While on a visit to her father in Jamaica, she was approached by an acquaintance who asked her to carry coconuts, rum and cans of coconut cream to England. She was apprehended at customs and cocaine was found in the cans:

I'm so embarrassed. I haven't told no-one. I keep going over in my head, what have I done wrong? What happened? Was I set up? Was I being duped? I don't know what happened to had 'little

discernible impact' on London's crack trade which quickly adapted to meet continuing demand (Russell et al., 2001). 
me. I told them the truth and they didn't believe me. I know so many people who lie to them and they get off, they get a few years. Its not fair. And then again the jury was all white and it was a verdict of 10 to 2 .

Maureen's case, she believes, was exacerbated by a customs officer who mistook her for another detainee and stated that she was carrying $£ 9,500$, rather than the few hundred pounds she actually had with her. In the face of racialized stereotypes of African Caribbean drug traffickers, Maureen's class status is erased. she is processed through the criminal justice system as 'just another' courier, found guilty by a predominantly white jury and given a mandatory minimum sentence.

While it may be tempting to draw a bold line between guilt and innocence in these two cases, the reality of women's involvement in importation is far more blurred. In many instances, importing was part of a complex emotional relationship between a male dealer or trafficker, often himself a minor player in the drug trade, and a lover/partner/'mule'. Diane, a biracial Canadian 25 year old, is serving the second-half of a five year sentence for importation at the Elizabeth Fry halfway house in Toronto. As a young woman, Diane left home and moved into a women's shelter because of her abusive relationship with her father. While she was there, she entered into a relationship with a Grenadan man who was subsequently arrested for drug dealing. While he was incarcerated, Diane visited him regularly and he discussed marriage with her. Shortly after his release, she gave up her job and started importing drugs for him, not knowing at the time that his previous courier had been arrested and incarcerated. She was not paid in cash for the trips she made, but occasionally, he would buy her expensive gifts such as jewelry and a computer:

He looked at it this way, he was paying the rent, he was paying for the food, he was paying the bills, if I needed anything l'd ask him for it. If I needed a new pair of shoes. But it was hard for me to ask him for anything because I don't like asking anybody for anything. I never got any money.

Diane and her partner were married before she was finally arrested and incarcerated at Grand Valley State, Kitchener. During the first few days of her sentence, she met the first courier and also learned that her husband had already moved in with another girlfriend. Nevertheless, she refused to trade information for a shorter sentence out of loyalty and respect for his paternal role:

I had been told don't implicate him because he's still on parole, so he'd do more time than I would, because he'd go back to jail to finish the remainder of his sentence, plus a new charge. So I figure I can't do that to him because l'd be taking the kids away from their father. And altogether I was with him for $71 / 2$ years.

Diane's case illustrates the complex web of emotion, economics and abuse that often draw women into criminalized activities. In her study of battered African American women, Beth Richie argues that 'gender entrapment' best describes the 
way in which black women are incarcerated due to their involvement with a coercive and violent male (Richie, 1996). While Diane was not subjected to physical violence, her partner's controlling behaviour in relation to the money which she generated through importation, the deception with regard to his other girlfriends, and his apparently cynical use of marriage as a means of controlling her labour form a web of abuse and exploitation. By controlling the labour of his 'stable of mules' through promises of love and commitment, Diane's partner generates wealth for himself without either taking the personal risk of importation, or paying the going rate of several thousand dollars per trip. This web of economic/ emotional exploitation was a factor in the stories of many of the women I interviewed. As Marta explained:

Men do it [import], but they tend to prey on the women more. Because they know that the woman in Jamaica, they care for their family, especially their kids. They would do anything to make sure their kids is looked after. So they mainly prey on the woman, especially single woman. You have men do it, but the number isn't as large as the woman.

Women's subordinate role in heterosexual relationships and their role as the primary and often sole carers of children combine to devalue their labour in the drug trade. The low value of women's labour in the drug trade is demonstrated by the women I interviewed who reported being 'set up' as decoys so that their arrest would distract customs officials from a larger shipment coming through. Paid anywhere from zero to a few thousand pounds for carrying a shipment worth upwards of $£ 100,000$, women form a cheap and replaceable army of labourers. As one is incarcerated, another, like Diane, quickly fills her place.

\section{the global feminization and racialization of poverty}

While transnational drug policies play an important role in channelling women of colour into prisons from Cape Town to Toronto, women are not without agency and do, of course, make choices within the options available to them. As the global economy has been transformed however, these options have become increasingly limited. In the global south, this economic transformation has driven a shift in the role of the state. Firstly, governments have been formed to scale down their role as providers of a social-welfare fabric as international financial institutions have driven neo-liberal economic reform. In Jamaica, policies introduced since the mid 1980 s by the Jamaican Labour Party working closely with the US, IMF and World Bank, have led to cutbacks in public sector employment, the scaling back of local government services, health and education, increases in the cost of public utilities as state owned companies are sold to the private sector and a dramatic decline in real wages. Such cuts hit women particularly hard as they carry the burden of 
caring for children and sick or elderly relatives (Harrison, 1991). Marta's experience exemplifies the increasing economic pressures facing women:

Things in Jamaica is very expensive. Its hard for a single woman with kids, especially anywhere over three kids, to get by without a good support or a steady job. It doesn't mean that I didn't have an income. I did have an income, but having four kids and an ex-husband who doesn't really care much. I had to keep paying school fees and the money kept going down. I did need some kind of support. That's why I did what I did. We don't get child support in Jamaica, three quarters of the things that this country offers for mothers here we don't have it. This country gives you a house, they give you benefits, we get nothing in Jamaica. We have to pay for hospital, not even education is free. Primary school used to be free under one government hand, but under another government it has been taken away. You're talking about high school, you're talking about fifteen up to twenty thousand dollars a term, for one kid to go to high school. Its difficult in Jamaica.

Secondly, while the state has cut back its role in social welfare, it has stepped up its role in subsidizing foreign and domestic capital. Free Trade Zones established in Kingston, Montego Bay and elsewhere offer foreign garment, electronic and communications companies equipped factory space, tax exemptions, a cheap

13 www.vegamedia. com/Jamaica. female workforce and, for the busy Executive, weekends of sun, sea and sand. ${ }^{13}$ Foreign-owned agribusiness and mining companies have also been encouraged, displacing traditional subsistence farming and causing migration from rural areas to the cities, which now account for $50 \%$ of the Jamaican population. As the economy has shifted, women working in the informal economy as farmers and 'higglers' find themselves unable to keep up with the rising costs of survival. While younger women may find employment in the tourist industry as maids, entertainers or prostitutes, or within the Free Trade Zones assembling clothes or computers for Western markets, working class women in their thirties and older have fewer options. Even where these women do find employment, low wages, driven down by multinational corporations in search of ever greater profit margins and kept low by governments unwilling to set a living minimum wage for fear of losing foreign investment, mean that they can not earn a sufficient income to support their families. The failure of the legal economy to provide adequate means for women's survival is the key incentive for those who chose to enter the drug trade as couriers.

The feminization of poverty in the global south is mirrored by conditions among black people and communities of colour in the West. As Naomi Klein argues, the flight of manufacturing jobs from the West to the global south has led to the Macdonaldization of jobs in North America and Europe, with part time, casual, low wage jobs the norm in the new service and 'homeworker' economies (Klein, 2001). At the same time, successive governments, whether espousing compassionate conservativism or the 'third way', have pursued market-led economic reforms which have dramatically reduced public services, introduced widespread 
privatization and raised the cost of living. The result is the disenfranchisement of working class and black communities and black women in particular as the state sheds its social welfare responsibilities. In Britain, as in the US and Canada, this has entailed a dramatic reform of welfare, and the targeting of single mothers in particular as a drain on the public purse. It is this impoverishment that acts as the motor to women's involvement within the retail end of the drug trade and their subsequent targeting by the criminal justice systems of these countries. Working class women, and in particular women of colour therefore bear the brunt of both the punitive and economic regimes of neo-liberal globalization. The devaluation of their labor within the criminalized economy of the international drug trade is closely interrelated to their superexploitation within the formal sectors of the global economy (the Free Trade Zones and minimum wage tourism and service sectors). Both are made possible by the radical feminization and racialization of poverty that is an essential part, rather than an unfortunate offshoot, of the corporate maximization of profits in the global arena.

\section{conclusion: towards resistance}

As the new millennium ushers in an era of unchecked capital accumulation and massive and widening divides between information-rich elites and disenfranchised majorities, feminists and anti-racists need to respond by infusing our praxis with the new politics. The new social movements of the 2 lst century are more likely to be found shutting down Niketown in San Francisco or battling the WTO in Seattle than at a take back the night rally or consultative meeting on institutional racism. While women of the global south and disenfranchised communities of the north have been active in vibrant anti-globalization protests, feminist scholars have been slower to identify corporate globalization as central to their concerns. Gradually, a body of knowledge is being developed that can serve as a valuable resource for feminist and anti-racist organizers as well as anti-globalization activists. Research into sex tourism, the trafficking of women, women as workers in the free trade zones and homeworkers in the garment industry and women in the global food chain have all demonstrated the centrality of black women and women of colour to the new global regimes of accumulation (Phizacklea, 1990; Kempadoo, 1999; Ching Yoon Louie, 2001; Shiva, 2001). Less attention has been paid to the repressive penal regimes that underpin these processes. The 'prison-like' conditions under which women labour in the free trade zones, with restricted access to restrooms, forced overtime and punitive sanctions for union activities and pregnancy, have generated considerable outrage among researchers and activists alike (Klein, 2001). The confinement of increasing numbers of women in the prisons and jails of the global north, where they are subject to separation, sometimes permanent, from children, sexual abuse, medical neglect and forced labour has, however, been muted. 
Perhaps the explanation for this muted response lies in a failure to connect women's incarceration to the social, economic and environmental concerns generated by the new global economy. The prison has traditionally served the purpose of separating those who have 'offended' from the social body politic. Prisoners are therefore seen as 'criminals' whose behaviour is qualitatively different from that of 'normal' people and must therefore be analysed using different tools, hence the existence of criminology as a distinct discipline. Yet if the complex web that has led to the massive increases in women's (and men's) imprisonment documented in this article is to be understood and challenged, prisons must be liberated from the criminologists and criminal justice professionals, and brought under the scrutiny of anti-globalization, feminist and anti-racist scholars and activists. Prisons serve a vital role in suppressing dissent and invisibilizing disenfranchised populations. They therefore maintain the viability of corporate globalization and mask its devastating effects on global majority communities. Prisons also play a direct role in capital accumulation since their operation generates profit for corporations engaged in building, equipping and operating them as well as those employing prisoners as cheap labour. Increasingly, black women and women of colour are the raw material that fuel the prison industrial complex: as scapegoats of tough-on-crime rhetoric; targets of drug busting operations that generate millions for police, customs and military budgets; or workers sewing and assembling electronics in prison workshops. There is a need for a new anti-racist feminism that will explore how the complex matrix of race, class, gender and nationality meshes with

contemporary globalized geo-political and economic realities. It must be transnational in scope and womanist in its integrated analysis of gender-raceclass and in locating black women and women of colour at the centre. As the gendered and racialized bodies that turn prison cells into profit margins, women of colour play a vital role in the global prison industrial complex. As activists, inside and outside of the prison walls, we are a critical part of the forces that are challenging its parasitic existence. The challenge for scholars and activists alike is to make visible the women hidden behind prison walls and to dismantle the profitable synergies between drug enforcement, the prison industry, international financial institutions, media and politicians that are celling black women in ever increasing numbers.

\section{author biography}

Julia Sudbury is Associate Professor of Ethnic Studies at Mills College, Oakland, USA and author of Other Kinds of Dreams: Black Women's Organizations and the Politics of Transformation (Routledge, 1998). She was formerly director of Sia, a national development agency for the black voluntary sector based in London and coordinator of Osaba Women's Center in Coventry. 


\section{references}

Albrecht, H-J. (2001) "The International System of Drug Control: developments and trends" in G. Jurg and E. Hensen (2001) (editors), Drug War, American Style: The Internationalization of Failed Policy and Its Alternatives, New York and London: Garland Publishing.

Bacon, W. and Pillemer, T. (2000) 'Violence blamed as women fill prison', Sydney Morning Herald www.smh.com.au/news/001/08/national/nationall.html, January 8.

Bean, P. (2001) 'American Influence on British Drug Policy' in G. Jurg and $\varepsilon$. Hensen (2001) editors, Drug War, American Style: The Internationalization of Failed Policy and Its Alternatives, New York and London: Garland Publishing..

Canadian Criminal Justice Association (2000) Aboriginal Peoples and the Criminal Justice System, Ottawa.

Churchill, W. (1990) Cointelpro Papers: Documents from the FB/s Secret Wars Against Domestic Dissent, Boston: South End Press.

Commission on System Racism in the Ontario Criminal Justice System (1994) Racism Behind Bars, Toronto: Queens Printers.

Currie, $\boldsymbol{\varepsilon}$. (1998) Crime and Punishment in America, New York: Henry Holt and Co.

Davis, A.y. (1998) 'Race and criminalization: black Americans and the punishment industry.' J. James (1998) editor, The Angela Y. Davis Reader., Malden, MA: Blackwell Publishers.

Dyer, J. (2000) The Perpetual Prisoner Machine: How America Profits from Crime, Boulder, Co: Westview Press.

Department of Justice (1998) Women in Criminal Justice: A Twenty Year Update. http:// www.usdoj.gov/reports/98Guide/wcjc98/execsumm.htm, accessed July 13, 2001.

Elkins, M., Gray, C. and Rogers, K. (2001) Prison Population Brief England and Wales April 2001, Home Office Research Development Statistics: London.

Friman, H.R. (1996) Narcodiplomacy: Exporting the US War on Drugs, Ithaca and London: Cornell University Press.

Goldberg, $\boldsymbol{\varepsilon}$. and Linda, $\boldsymbol{\varepsilon}$. (1998) The Prison Industrial Complex and the Global Economy, Berkeley, CA: Agit Press.

Hannah-Moffatt, K. and Shaw, M. (2000) An Ideal Prison?: Critical Essays on Women's Imprisonment in Canada, Halifax: Fernwood Publishing.

Harper, R. and Murphy, R. (1999) Drug Smuggling: an analysis of the traffickers 19991-1997, London: Middlesex Probation Service.

Harrison, F.V. (1991) 'Women in Jamaica's urban informal economy', in Mohanty, Chandra T., A. Russo and L. Torres (1991) edtors, Third World Women and the Politics of Feminism, Indiana University Press.

HMSO (1982) Prison Statistics England and Wales 1980, London: HMSO.

Joyce, Elizabeth (1998) 'Cocaine Trafficking and British Foreign Policy' in J. Elizabeth and C. Malamud (1998) editors, Latin America and the Multinational Drug Trade, Basingstoke: MacMillan Press.

Kempadoo, K. (1999) Sun, Sex and Gold (1998) editor, Rowman and Littlefield Publishing.

Klein, N. (2001) No Logo: Taking Aim at the Brand Bullies, Toronto: Vintage Canada.

Martin, W. (2001) 'Privatizing Prisons from the USA to SA: Controlling Dangerous Africans across the Atlantic, ACAS Bulletin, Winter 2001 \#59, http://acas.prairienet.org/Wackenhutv5.htm.

Morgan, R. (1999) 'New Labour 'law and order' politics and the House of Commons Home Affairs Committee Report on Alternatives to Prison Sentences." Punishment and Society. July l (1).

Oliver, M. and Shapiro, T. (1995) Black wealth, white wealth: a new perspective on racial inequality, London and New York: Routledge. 
Parliament of New South Wales, Select Committee on the Increase in Prisoner Population, www.parliament.nsw.gov.au, accessed july 4, 2001.

Phizacklea, A. (1990) Unpacking the Fashion Industry: Gender, Racism and Class in Production, London and New York: Routledge.

Prison Privatisation Report International (1996) 'Labour to Halt New Private Prisons', London: Prison Reform Trust.

Prison Privatisation Report International (1998a) 'UK profits'. Nov/Dec.

Prison Privatisation Report International (1998b) 'Labour's prison U-turn complete'. June.

Prison Reform Trust (2000) Justice For Women: The Need for Reform, London: Prison Reform Trust.

Richie, B. (1996) Compelled To Crime: The Gender Entrapment of Battered Black Women, London and New York: Routledge.

Rojas, P.M. (1998) 'Complex Facts' Colorlines, Fall.

Rose, D. 'Opium of the People' The Guardian Sunday, July 8th, 2001.

Speller, A. (1996) Private Sector Involvement in Prisons, London: Church House Publishing.

Smith, K. (1999) 'From the Desk of Kemba Smith' www.geocities.com/CapitolHill/Lobby/8899/ pen.html, December 13, 1999.

Sudbury, J. (2000) 'Transatlantic Visions: Resisting The Globalization of Mass Incarceration', Social Justice Winter.

Sudbury, J. (2001) (forthcoming) 'Globalisation, Incarcerated Black Women/ Women of Colour and the Challenge to Feminist Scholarship', Women's Studies Network.

Waters, M. (1998) 'Congressional Black Caucus Blasts President's Crack/ Powder Cocaine Sentencing Recommendations', Press Release, July 22, 1998.

Yeoman, B. (2000) 'Steeltown Lockdown', Mother Jones May/June 2000.

Young, P. (1987) The Prison Cell, London: Adam Smith Institute.

Van Der Veen, H. (2000) The International Drug Complex Amsterdam: Center for Drug Research, University of Amsterdam.

doi:10.1057/palgrave.fr. 9400215 